\title{
Editorial
}

\section{Ethnography facing the current challenger of social sciences}

\author{
Consuelo Biskupovic ${ }^{1}$ and \\ Guillermo Brinck Pinsent ${ }^{2}$
}

In the framework of a multidisciplinary meeting on ethnography held in 2017 at Universidad Academia de Humanismo Cristiano in Chile, there was a question essential to open this dossier. That question was about what brings us together today, what makes us live together, sharing resources and being together. We reflect about possible answers from social sciences and on how to produce those answers. Ethnography undoubtedly seems to be the primary tool to study the "living," the permanence and in situ observation of the researcher. Practicing ethnography implies collaboration. It is considered as a technique of coupling instead of imitation that assumes the impossibility of confusing with the others as well as the intervention of the researcher in the observed communities: we are not neutral, we participate in that sharing; we are not omniscient narrators of life in society because we are a part. In order to answer these basic questions about living, ethnography is a process al-

\footnotetext{
Antropology Doctor by École des Hautes Études en Sciences Sociales, Paris, researcher and professor in Universidad Academia de Humanismo Cristiano. E-mail contact: cbiskupovic@gmail.com

2 Doctoral candidate in Antropology by École des Hautes Études en Sciences Sociales, Paris, researcher and professor in Universidad Academia de Humanismo Cristiano. E-mail contact: gpbrinck@gmail.com
} 
lowing us to observe behaviors and helping to ensure our data's reliability by obtaining them by "first hand."

From these consensuses it is possible to verify that, beyond the different models in ethnography, this is a conscious way of being and developing an experience. That is not exhausted in a literal reading of what Malinowski proposed when he wrote that "the closer you live from a village and the more you really see natives, the better" (Álvarez, 1994: 94.) Virtual ethnography, for example, invites us to discuss the classic idea of closeness and seeing «really» or directly, allowing us not to be there in the flesh but maintaining a digital presence either through writing, image, perceptions and representations. Ethnography is not just a personal experience, it is a way of working not only related with people and no longer limited to "living as close as possible to a village.» Ethnography aims at describing life as it is experienced by people somewhere and at some time, as Ingold (2017) said. This does not imply only to «accompany,» witness, observe ... but also to create new co-presences and strategies to study the different ways of living and being in the world.

As we see in this thematic issue, contexts from which ethnography can be thought (State, political mobilization, migrations or interethnic relations) are not exclusive since they are totally connected and it is difficult to think ethnography without considering the identity frameworks, the role of the State and powers, so on.

Although anthropologists often turn to Malinowski, questions change when «natives» or «others» are no longer at the center of interest. We are facing virtual machines, «bot,» blogs, institutions, systems, territories or landscapes as heterotopic as Antarctica. ${ }^{3}$ As explained by Leticia Katzer in her article includ-

\footnotetext{
Entre las ponencias en el marco de las Primeras Jornadas de Etnografía realizadas en noviembre de 2017 en la UAHC, contamos con la exposición de Juan Francisco Salazar "Especulación fabulativa y etnografia" de la University of Western Sydney.
} 
ed in this dossier, "stories and forms of relationship constructed within ethnographies have been and continue to be of the most dissimilar." However, even though new ethnographic searches have explored more alternatives than "living as close to a village," there are certain issues constantly re-starting from the ethnographic experience in social sciences. Behind the idea of traditional institutions, citizenship, social methods, politics or the State, there are some of the reflections framing this issue. Institutions, ideas and categories are studied more than as macro structures, stable and rigid; ethnography allows us to account for their incarnated version. Thus, in some cases, the State is embodied in one or two people to deal with.

Interest to open these questions and account for the density behind the categories responds to both the diversity of ethnography as a tool and perspective, as well as the boom it has. While this diversity has opened the possibility of showing aspects that would not be possible to know through the so-called qualitative techniques of social research, the paradox is that ethnography has become such a widely used concept in various disciplines that it loses much of its meaning (Ingold, 2014.) From a controversial vision, anthropologist Tim Ingold is concerned at defining the limits of ethnography in order to avoid term abuses. This venture might seem conservative if we think, as we said before, that ethnographies are dissimilar, but Ingold is right when he points out that ethnography now seems to be synonymous with qualitative. An interview can be labeled as "ethnographic" in a report or investigation when it comes to previously selected informants and the information obtained is analyzed with software to produce "outcomes," without any reference to the context and practices of those interviewed (Ingold, 2014). This would undermine the seemingly sharp principles that are the basis of ethnography:

En su intervención sobre cómo hacer una etnografía en la Antártica, Francisco explicó como realizó una película etnográfica en este territorio extremo. For more information, see this digital resource: https://vimeo.com/juansalazar 
rigor and "long time" commitment, deep and sensitive bonds related to the context in which we live.

Participant observation is the focus of ethnography, questioning our assumptions about the world (Shah, 2017.) This is not typical of anthropology, as we will see in the articles in this dossier, but it is a form of knowledge production through being and action (Shah, 2017.) As this author points out, this implies a long duration, to holistically understand relationships of a group, which is, to study all aspects of social life and to include intimacy and distance with those "strangers" that we include in our research, were they human or non-human. Alpa Shah adds that getting involved in these steps is a political act allowing us to challenge the hegemonic conceptions of the world and powers. Therefore, it may not be something specific to anthropology, but it calls for all social sciences and beyond them.

As we pointed out, general context of conditions for producing knowledge has imposed its demands: the methodological standard of sociology, for example, involved the adaptation of participant observation to positivist demands (Ingold, 2014.) This has generated a significant change in the way of working in the field, which, in a framework increasingly oriented towards the production of articles rather than monographs, implies a transformation of ethnography as a literary genre, or even its disappearance at only mentioning the method used.

Contrary to an ethnographic "standard," as existed between 1900 and 1960, according to James Clifford (1983), the progressive transformations with respect to ethnography in the different disciplines have not been systematic nor homogenous everywhere. There are regional differences of theoretical and disciplinary orientation regarding what is understood by ethnography and what are the criteria that make ethnographic work acceptable. Social sciences speak a multiplicity of languages and, when ethnography is named, there is no allusion to a univocal object. However, it is difficult to yield to the idea of ethnography as synonymous with an 
experience founded on the ground and in the "long time," to take up the expression that Braudel used with respect to history (Noiriel, 2002.) Or rather, we believe that we should not give up this long time, to the years on the field (refer to a geographical, virtual or other space). As Braudel (1958) pointed out, either in relation to the past or the present, a common and transversal methodology in the sciences that study humans should consider the plurality of "social time," that is, the moment, the slow time, the duration...the history of the very long duration, beyond decades, hundreds of years. That time that goes beyond events, which are often deceptive and do not allow us to understand social life beyond "milestones." The focus in this long time "is indispensable for a common methodology in sciences of men" (Braudel, 1958: 726.)

\section{Celebrity of ethnography among social sciences}

Actually, ethnography has been consecrated as one of the ways of creating relevant knowledge in social sciences. In the last two decades, ethnographic studies have multiplied as much as their acceptance (Culyba, Heimer, \& Petty, 2004.) Even in the Big Data era, when data are processed algorithmically in proportions never seen before, there is a need to complement them with ethnography in order to root and contextualize the raw data, obtaining what has been called as Thick Data (Alles \& Vasarhelyi, 2014; Wang, 2013.) It has been reasonably said that everyone may do ethnography (Sharma, 2016,) and so, together with the classic monographs dedicated to indigenous peoples located in some distant part of the globe, we have ethnographies of consumption, media, the State, the bedroom, Internet, social networks, the Army, prisons, psychiatric hospitals, marginal villages, gangs or the sale of drugs in urban centers. Although ethnography is closely linked to anthropology, today participant observation is a practice that transcends disciplines.

Despite problems generating a lack of agreement on the definition of ethnography (Ingold, 2017,) without a univocal meaning 
it has been able to self-adapt to different disciplines facilitating their mutual collaboration. It is possible to combine definitions, to experiment, to transfer concepts, assuming that a single term may describe a plurality of different senses and practices. Ethnography is far from being a mathematical equation or a statistical result (which does not prevent research may be conducted combining ethnography, mathematics and statistics.)

Currently there are a variety of ways to practice ethnography. Dominant sociology, marked by a methodology inherited from positivism, receives in a better way naturalistic rather than experimental ethnographies (interpretative, reflective, collaborative, performative ethnography, self-ethnography, so on). These abound in anthropology and practitioners of the qualitative approach of social research such as symbolic interactionists, as well as those who are counted among the ranks of postcolonial studies and feminism (Culyba et al., 2004.) There are many sociological works based on an intensive ethnography with high methodological standards and a deep epistemological reflection in diverse urban contexts, a reflection that can be found in an article transcribed from a talk by Erving Goffman in 1974 (Goffman, 1989), where he talks about his job. It is interesting to deepen this question of how we work, because that is where the main field of ethnography lies. Works such as Loïc Wacquant (2006) on boxing, Phillipe Bourgoise (2010) on the sale of drugs in New York or Javier Auyero and Débora Swistun (2008) on environmental suffering in the city of Buenos Aires are good examples of intensive ethnographies carried out in "non-exotic" contexts.

Despite this and the proliferation of journals and manuals on qualitative methods and techniques in social research where more and more ethnographic works are published, the general tendency in world sociology has been to tangentially incorporate ethnography more as a fashion or as a way to complement the quantitative data, including some days of field work or referring to the ethnographic work of others to contextualize their own generalizations (Culyba et al., 2004.) In this auxiliary use 
of ethnography, participant observation is seen as a technique that delivers data with the same epistemological status although quantitatively different. In this same sense, the applied use of ethnography in social communication, design, consumption and public policies tends to emphasize the technical aspects of participant observation aimed at producing specific information for some practical purpose. In them, ethnography is not a specific mode of knowledge but a technique within a methodological design.

However, from its origins, the ethnographic practice has presented epistemological, methodological, theoretical, ethical and political challenges, which have not been eliminated using the rhetoric of a methodological design.

In all the variety of perspectives that contains the same term, difficulties of understanding and risks of discredit are great. For this reason, an interdisciplinary dialogue is necessary to circumscribe the limits of ethnography sustaining collaboration in social sciences and beyond them. This dossier aims to be a contribution to this dialogue through a sample of different ways of doing and conceiving ethnography.

\section{Artisan work based on experience}

Historically, ethnography has been almost synonymous with anthropology. Indeed, the tradition of the anthropological tribe makes ethnographic fieldwork the rite of passage necessary to become a complete professional, and the journey that Bronislaw Malinowski capped with the publication of Argonauts of the Western Pacific in 1922 his myth of origin (Stocking, 1985.) However, while it is true that it is impossible to think anthropology without ethnographic field work, participant observation has existed without anthropology, since it has had diverse origins. To begin with, all the German ethnography practiced within the diffusionist ethnological school at the end of the 19th Century and the beginning of the 20th Century is legitimately 
claimed by human geography and sociocultural anthropology (Canal, 2018.) On the other hand, participant observation was developed autonomously at the Chicago School of Symbolic Interactionism or cultural studies such as those by Paul Willis to respond to problems that were posed (Restrepo, 2018.) In spite of this, most current ethnographic work is carried out by anthropological professionals in conditions that have given them their characteristics: participant observation with full-time permanence and for prolonged social practices and the meaning that those practices have for the very actors (Guber, 2004, 2017, Restrepo, 2018.) These conditions, established in the late Nineteenth Century and embodied in the figure of Malinowski, are those still applied to any ethnographic work, regardless of the circumstances in which they are carried out, whether in an indigenous community, digital social networks or in the study of a public policy. It is evident that ethnography has undergone important transformations, such as the world in which it is placed. Thus, from ethnographies located in remote and isolated spaces, as if the observed people were out of time and from external influence in an eternal ethnographic present (Fabian, 2002), the situational approach was developed to understand - from a microscopic point of view - structures that made inter-ethnic relations intelligible in the cities of southern Africa during the colonial period (Balandier, 1970, Gluckman, 2003, Mitchell, 1959, Van Velsen, 1978); and began to make historical (Sahlins, 1997, 2001) and multi-sited (Hannerz, 2003, Marcus, 1995) ethnographies that consider the way in which actors and groups are related to the political, economic and cultural system on a world scale, becoming considered contemporary rather than primitive or even cosmopolitan (Agier, 2012, Althabe, 2003, Augé, 1995.) These changes have required the development of interdisciplinarity and the incorporation of various techniques, technologies and forms of quantitative and qualitative analysis to make the field survey viable. However, ethnography remains an artisan practice since its success depends on the encountering experi- 
ence between the observer person and the observed person in the context of their daily interactions.

\section{Complexities of a term}

Personal experiences on which ethnography is based make it different from qualitative research techniques since in it the observer does not self-limit to collecting data as if data were waiting to be collected and analyzed, but she or he is ontologically committed (Ingold, 2017) in a process of co-knowledge with those people making up the context to understand. Due to ethnography wants to describe the structure of a group, community, context, and the sense given to actions of subjects composing it in this context, the ethnographic venture depends on a particular sensitivity towards "a culturally established way of being and seeing the world" (McGranahan, 2018, p.2.) Ethnography would be ontological and epistemological at the same time (McGranahan, 2018,) which undoubtedly hinders its inclusion in the canons of the prevailing methodological design in social sciences (Ingold, 2017).

The word ethnography may refer simultaneously to an approach, a method and a text (Guber, 2017) or to a technique, a method and a type of writing (Restrepo, 2018); or to a theory, a method and a form of writing (McGranahan, 2018.) As said, ethnography is often seen only as a technique, participant observation, which means limiting the total social experience the observer could have observing the information gathering activities, turning their interactions as instrumental and their interlocutors as informants, denying the purpose of ethnography, which is to observe relationships in their natural context by participating in them. So if ethnography has a technical dimension, it may not embrace it without sacrificing what defines it. Anthropologist Carole McGranahan has defined anthropological ethnography as "a practice of empirical and experiential body knowledge, based on fieldwork and participant observation" (McGranahan, 
2018, p.4.) Long time before, in 1974, Ervin Goffman defined participant observation as a technique, but a technique "in which seemingly data are obtained by self-submitting, in body and personality, and own social situation, to all contingencies affecting a group of individuals, so that it is possible to physically and ecologically penetrate their circle of responses to their social situation, or their work situation, or ethnic situation, or whatever" (Goffman, 1989, p.125.) So, both in anthropology and in sociology (at least in symbolic interactionism), ethnography has been understood and practiced as a total personal experience. That's why so often people who work in ethnography define themselves as ethnographers rather than as observers or researchers (Mannay \& Morgan, 2015.)

Obviously, not all fields allow the same conditions, and objects of the various disciplines have stressed these factors, naming as ethnography practices that are far from deep immersion and permanent stay in the field to actively participate in all possible instances. Ethnography in cyberspace, for example, does not imply a bodily experience; working in hierarchical institutions, such as the Army or a psychiatric hospital, does not allow full participation and is often limited to conducting interviews; working with prisoners in a prison imposes a barrier to those who, without being a prisoner, want to carry out an ethnographic work. And yet we have ethnographies about these contexts. One response has been to adapt the method to the field conditions (as well as to the budget and the increasingly pressing deadlines of requesters,) as with the so-called floating observation (Pétonnet, 1982), which emulates the city walker in order to incorporate rhythms and flows of an urban space always in formation. Or the so-called focused ethnography (Knoblauch, 2005,) which is presented as a complementary version of conventional sort-term ethnography but intense communicative interaction. The other response is developing a device for monitoring observation and participation in ethnography, as a holistic approach of epistemological and existential scope at the same time. 


\section{Ethnography, method and reflexivity}

In this scenario it is valid to ask what would be the limits of ethnography, what distinguishes it from the participant observation and how a method or technique may guarantee rigor in these times and these characteristics of the context. In what sense may we speak of ethnography when the research work is almost entirely restricted to in-depth interviews? As we have seen, there are those who affirm that an interview could never be ethnographic (Ingold, 2017.) For others, such as Eduardo Restrepo or Rosana Guber, an interview may be ethnographic insofar as it takes into account what is said as an expression of what is being done in the interview situation, considered as a social relationship. In this way, ethnography as a method or epistemological framework considers a series of techniques (participant observation, interviews, genealogies, life stories) having an ethnographic sense when assuming a context of sociocultural production (Restrepo, 2018.) Following Harold Garfinkel, Rosana Guber emphasizes reflexivity of actors both at the moment of producing the interactions adequate for the context studied and those adequate to the study of that context (Guber, 2017.) Thus, information (answers to direct questions in an interview, and interactions and activities observed in the ethnographer's participation) is not an objective reflection of a transcendent context (structure, culture, identity, so on), but the result of multiple reflexivities considering and reacting to the ethnographer's presence, attributes, actions and questions. It is the task of the observer to work these apparent distortions as ethnographic data in order to restore the social meaning of the actors' actions and sayings.

This is what Jaime González means in his article published in this dossier on indigenous intellectuals when, following Giddens, he assumes the need to consider the "double hermeneutics" of the ethnographic situation: "field research with these agents will also depend on the interpretation capacity of the study subjects and the effect that this will generate in the interaction with the 
researcher. In this way, intellectual tendencies that may be identified in the field will be mediated by the awareness of these agents and their intellectual reading of the ethnographer they have in front." Likewise, Olivia Leal, in the text here published, analyzes "processes of bidirectional interpellation between the ethnic subjects and the ethnographer about data collected, forms of registration and order of information shaping the final ethnographic text as a whole. In fact, as an ethnic group, they considered my own thesis as part of their material heritage, since I report "only a part of all that may be said about Chilas."

In our opinion, this is an essential component of ethnography. It is not just about observing, but about maintaining attention (floating or directed) and epistemological surveillance. In this sense, interactions in participant observation resemble relationships established in psychoanalysis where the material analyzed are the objectified memories of the patient such as the transference and the counter-transference in which his or her basic conflicts are repeated, projecting them into the figure of the analyst to the extent that the analyst also reacts. In ethnographic work, this specular game must be registered and considered even when a survey, interview or genealogy is applied, considering the analysis of the transference and the countertransference, and even with greater emphasis on the second, since it will allow controlling the production and analysis of data (Devereux, 2008.) This does not necessarily imply an obsessive turn on questions of ethnographic authority and crisis of representation. Neither does it imply granting a privilege to the "self-ethnographic" (although it certainly gives it an epistemological foundation), since ethnography must always describe a concrete reality in trustworthy terms and rigorous manner. Ethnography must say something about its object (not subjects themselves,) about the relationship between the same and the other, the game of alterities and the social meaning deriving from them (Augé, 1995, 1996.) For this to be achieved, ethnography must be considered as a situated knowledge in which 
reflexivities of one and the other in the same research provide a relation of the same nature as that it is seeking to describe. Maybe this is the main difficulty of ethnography "methodologization," the fact that it is only a posteriori method, when observations made in the context of interaction and recorded in the field notebook become part of a written or visual description aiming at understanding or explaining a general phenomenon in a particular context (Ingold, 2017.)

\section{Ethnographic knowledge, embodied experience and academic policies}

The situated nature of ethnographic knowledge has given rise to talk about ethnographic theory (da Col \& Graeber, 2011, McGranahan, 2018.) Beyond controversies regarding the theoretical perspective implied by this expression (Ingold, 2017), the question of the generalized scope of knowledge about restricted contexts such as those usually addressed by ethnographers (village, classroom, institution, neighborhood, so on) has been defined by Clifford Geertz appealing to the microscopic nature of ethnographic knowledge insofar as it does not study small localities but studies deep and far-reaching issues in these places through what he calls dense description, which corresponds to explain the facts appealing to the social meaning of action (Geertz, 1992.) Thus, it would be possible to speak of ethnographic knowledge insofar as it accounts for embodied concepts in a concrete socio-culturally informed experience. This way of constructing knowledge, confronting local notions, concepts and models with theoretical models, concepts and notions elaborated in the academy, allows to renew and permanently increase the conceptual repertoire of social sciences. Insofar as ethnographic knowledge supposes an exposure to a different configuration of reality and experience, it also enables a theoretical and epistemological crisis, an ontological crisis in the ethnographer he or she tries to express in his or her ethnographic description. 
In her article published in this dossier, Leticia Katzer affirms that "specificity of ethnography is being a conception and practice of knowledge that seeks to understand social phenomena from the perspective of its members (Guber 1991 [2004], 2001). This is only possible when a relationship between the ethnographer and those others is authentically established." The author adds that "ethnographic relationships" on the ground guided her academic activities, decisions and research questions. This process is fundamental and necessary even when the evaluation criteria nowadays (whether for funds, projects or measuring productivity or publications) constrains researchers to circumscribe research within a short term, to quantify interviews and measure results. The challenge of carrying out long-time ethnographies in an academic context marked by maximization of time and results in research is very complex, today more than ever.

In this context, more than other social sciences' disciplines, anthropology is questioned in its "scientific" rigor and systematics, its ability to produce "reliable knowledge" through ethnography, leading it to predefine "representative samples" in advance. Although population studied in research are not homogeneous and therefore central to account for diversity, this may not always be explained through a representative sample. Many times ethnography focuses on groups that have certain similar ideas, or that belong to similar groups and/or classes, for example, when studying a political party, an NGO, or tattooing in a group of young people. Wealth is not always in the "representativity" to answer the research question, but also in the particularity, in what makes that group unique, in its characteristics, in the selfperception of its members, in their existence as a group. Ethnography allows us to track motivations and meanings of those involved, how they live and interpret their lives, their belonging to social groups or categories, and their own existence.

As a field experience, ethnography modifies our questions as well as the questions we ask to "natives" and what we observe. In this framework, the way people we interact with account 
for their environment, explain and reflect with ethnographers should be seen, as Julieta Quirós suggests, "rather as an 'intellectual' point of view (i.e.: ways of conceiving and meaning worlds) as an 'experiential' point of view (ways of making and creating social life)" (Quirós, 2015: 47.)

Many aspects focused in the monographs did not seem relevant nor even were considered in the initial phase of research design. And it is common for new problems and new questions to emerge in the field. In this sense, a distinctive feature of ethnography is that it opens up new questions rather than circumscribing issues. As we have said, in this back and forth dynamics from the field, reflexivity resulting from shared experience, from "exposure" and from experience are central parts of ethnography. However, these sensitivities and commitments do not fit with the frameworks and standards increasingly demanded in protocols to obtain research funds, scholarships, evaluations and work reports. Even more when "the research question is never a known formulation. The object and research questions are precisely part of what we are looking for in the field" (op cit.: 54.) This is a real challenge for both, the student body making and justifying ethnographies, and for researchers who must "adapt" ethnography to standards, requirements and forms of the current academic field. On the other hand, ethnographic research must adapt to the format of scientific articles, accommodating all components of a scientific work as well as ethnographic data, context and situation, requiring a much larger space than tables of quantitative data or quotes from qualitative research interviews, in order to always refer to a problem of general scope that is relevant to them and insert them into the field of disciplinary or thematic reflection. No matter how new worlds to explore may arise (digital citations, prison worlds, scientists based in Antarctica, so on), it is possible to determine that ethnography is a method, a technique and a solid and ductile mode of writing to face these new challenges. Today we make a proof of this. 


\section{How the dossier is organized}

The dossier presented in this issue includes eight articles that are classified into four major themes. The first two articles allow to historically and theoretically contextualize ethnography as a concept. The article "Ethnography and Empiricism" by Cristopher Valdés San Martin addresses ethnography from an epistemological reflection and following a phenomenological consideration of its history, mainly from Husserl's perspective. He argues that anthropological knowledge is distinguished by its totalizing desire in the search to compose the "world" of others from a non-conceptual knowledge and attached to the experience that nevertheless allows the emergence of a philosophical subject. The article "Desert Ethnographies. Reflections from an anthropology of nomadism" by Leticia Katzer combines a critical reflection on ethnography with her own field experience with Huarpe indigenous people in Mendoza province, Argentina. She dialogues with the continental philosophy of Derrida, Cacciara, Deleuze and Guattari, proposing it as an expression of nomadic science insofar as it focuses on the trace and the spectrum rather than on regularities leading to closed models. In this way, Katzer talks about her process and her ethnographic experience with poststructuralist philosophy to give foundation to her proposal of collaborative ethnography.

Then, from a political ethnography, Pia Rus' work allows to see "what is behind" the apparent. Rius researches "the experience of politics" in order to see how a population daily self-manages "collective organization, work, food or cultural production and consumption." The long time of her ethnography allows her to apprehend a temporality revealing how to define "work without a 'patron'".

From the global problem faced by migrants today, work of Alberto Farías "Ethnographic looks and representations of citizenship in young indigenous, Purépecha migrants from Mexico" also reflects from a political ethnography on Purépecha indig- 
enous migration to the United States. He presents the results of a qualitative, collaborative and ethnographic research about the situation of discrimination and racism experienced by Purépecha youths after having migrated and returned to their communities of origin in Mexico. This work accounts for a complex problem that is the practices of contemporary discrimination and racism, considering the indigenous communities in their possibilities in the current context.

This dossier presents two urban ethnographies. The authors of the first one ("Institutional ethnography as an approach to daily life"), Jirón, Orellana and Imilán, describe in detail what is Institutional Ethnography and explain how this approach is applicable to the studies of urban living. In particular, authors focus on the case of the Chilean Neighborhood Recovery Program Quiero Mi Barrio (by Chilean Housing and Urban Ministry), in knowledge as a mediation between those living in a neighborhood at Santiago and the very intervention, as well as the institutional regime around that intervention. According to them, the Institutional Ethnography is more than studying everyday experiences, proposing to investigate "social relations, organization and control relationships" that "emerge from the institutional complexes coordinating and managing these experiences."

The second work is written by Olivia Leal Sorcia, "Challenges for ethnographic work with urban Indians in Mexican cities." In this text, Leal elaborates a critical reflection on the ethnographic method and its techniques (participant observation, field notebook and in-depth interviews) from her field work with indigenous residents in Mexico City (chilangos), considering challenges posed by the agency of actors in the way the ethnographer registers, analyzes and writes, and the role that their writings play in the phenomenon they seek to understand.

The dossier is finally closed with two ethnographies addressing different ethnic cases. The first work, "Ethnic Intellectuality. 
A theoretical-methodological proposal for an object of inquiry" by Jaime González, develops a model to understand the ethnic intelligentsia on the basis of an ethnographic experience between Purhépecha people of Mexico and Aymara people of Chile. It shows the versatility of the ethnographic method in subjects for whom the method was not designed. The text considers the difficulties of this non-traditional research, indicating the need to incorporate the analysis of double hermeneutics occurring in the ethnographic situation where, as the researcher, intellectuals have academic degrees and a level of knowledge agency the ethnographic process deals with.

The text by Roberto Narváez Collaguazo entitled "Ethnography: A research instrument in legal anthropology. The case of Amazon people" deepens the socio-cultural foundations of war in the case of the Waorani at the Ecuadorian Amazon from the perspective of legal anthropology, showing the extent to which ethnography is relevant to this subdiscipline. Constantly referencing to the field notebook, this text shows the way in which revenge, strategies and alliances are part of a way of living together in ways such as assaults, skirmishes and confrontations, all of which are judged by the State as faults to the law and civic order but that may be understood from an ethnographic perspective as part of a traditional way of participating in social life and being recognized by others.

This dossier presents an interesting diversity of themes, phenomena and theoretical, methodological and epistemological issues around ethnography. We trust that this selection is not only a sample of the way in which ethnographers are practicing ethnography and issues raised about this practice, but it will also help to facilitate dialogue among people who come from different countries, disciplines and social, cultural, ideological and intellectual traditions. 


\section{Bibliography}

Agier, M. (2012). Pensar el sujeto, descentrar la antropología. Cuadernos de antropología social, (35), 9-27.

Alles, M., \& Vasarhelyi, M. A. (2014). Thick data: adding context to big data to enhance auditability. International Journal of Auditing Technology, 2(2), 95-108. https://doi.org/10.1504/IJAUDIT.2014.066237

Althabe, G. (2003). Antropología del mundo contemporáneo y trabajo de campo. Alteridades, 13(25), 7-12.

Álvarez Roldan, A. (1994). La invención del método etnográfico: reflexiones sobre el trabajo de campo de Malinowski en Melanesia. Antropología. Asociación madrileña de antropología, 1994, 83-100.

Atkinson, P. (2015). For ethnography. Los Angeles: SAGE.

Augé, M. (1995). Hacia una antropología de los mundos contemporáneos (1a. ed). Barcelona, España: Gedisa.

Augé, M. (1996). El sentido de los otros: actualidad de la antropología (1a.ed). Barcelona, España: Paidós.

Auyero, J., \& Swistun, D. A. (2008). Inflamable: estudio del sufrimiento ambiental (1a ed). Buenos Aires: Paidós.

Balandier, G. (1970). El concepto de «situación» colonial. Guatemala: Ministerio de Educación.

Bourgois, P. I. (2010). En busca de respeto: la venta de crack en Harlem. San Juan, P.R.: Ediciones Huracán.

Braudel, F. (1958). Histoire et Sciences sociales : La longue durée. Annales, 13(4), 725-753. https://doi.org/10.3406/ahess.1958.2781

Canal, R. de la. (2018). La Geografía y la Antropología: vinculaciones en sus recorridos históricos. Huellas, 22(2), 99-105. https:/ / doi. org/DOI: http:/ /dx.doi.org/10.19137/huellas-2018-2215

Culyba, R. J., Heimer, C. A., \& Petty, J. C. (2004). The Ethnographic Turn: Fact, Fashion, or Fiction? Qualitative Sociology, 27(4), 365-389. https://doi.org/10.1023/ B:QUAS.0000049238.27735.79

da Col, G., \& Graeber, D. (2011). Foreword: The return of ethnographic theory. HAU: Journal of Ethnographic Theory, 1(1), vi-xxxv. https://doi.org/10.14318/hau1.1.001 
Devereux, G. (2008). De la ansiedad al método en las ciencias del comportamiento. México, D.F.: Siglo Veintiuno.

Fabian, J. (2002). Time and the other: how anthropology makes its object. New York: Columbia University Press.

Geertz, C. (1992). Descripción densa: hacia una teoría interpretativa de la cultura. En La interpretación de las culturas (pp. 19-41). Barcelona: Gedisa Editorial.

Gluckman, M. (2003). Análisis de una situación social en zululandia moderna max gluckman la organización social. Bricolage, (1), 34-49.

Goffman, E. (1989). On fieldwork. Journal of Contemporary Ethnography, 18(2), 123-132. https://doi. org/10.1177/089124189018002001

Guber, R. (2004). El salvaje metropolitano: reconstrucción del conocimiento social en el trabajo de campo (1rst. ed. In Editorial Paidós). Buenos Aires: Paidós.

Guber, R. (2017). La etnografía: método, campo y reflexividad. Ciudad de México: Siglo XXI Editores.

Hannerz, U. (2003). Being there... and there... and there!: Reflections on Multi-Site Ethnography. Ethnography, 4(2), 201-216. https: / / doi.org/10.1177/14661381030042003

Ingold, T. (2014). That's enough about ethnography! HAU: Journal of Ethnographic Theory, 4(1), 383-395. https:/ / doi.org/10.14318/ hau4.1.021

Ingold, T. (2017). ¡Suficiente con la etnografía! Revista Colombiana de Antropología, 53(2), 143-159.

Knoblauch, H. (2005). Focused Ethnography. Forum Qualitative Sozialforschung / Forum: Qualitative Social Research, 6(3). https: / / doi.org/10.17169/fqs-6.3.20

Mannay, D., \& Morgan, M. (2015). Doing ethnography or applying a qualitative technique? Reflections from the 'waiting field'. Qualitative Research, 15(2), 166-182. https://doi. org/10.1177/1468794113517391

Marcus, G. E. (1995). Ethnography in/of the World System: The Emergence of Multi-Sited Ethnography. Annual Review of Anthropology, 24(1), 95-117. https://doi.org/10.1146/annurev. an.24.100195.000523

McGranahan, C. (2018). Ethnography beyond method: the importan- 
ce of an ethnographic sensibility. Sites: A Journal of Social Anthropology \& Cultural Studies, 15(1).

Mitchell, J. C. (1959). The Kalela dance: aspects of social relationships among urban Africans in Northern Rhodesia. Manchester: Manchester University Press.

Noiriel, G. (2002). Comment on récrit l'histoire. Les usages du temps dans les Écrits sur l'histoire de Fernand Braudel. Reoue d'histoire du XIXe siècle. Société d'histoire de la révolution de 1848 et des révolutions du XIXe siècle, (25), 57-81. https:/ / doi. org $/ 10.4000 /$ rh19.419

Pétonnet, C. (1982). L'Observation flottante. L'exemple d'un cimetière parisien. L'Homme, 22(4), 37-47. https://doi.org/10.3406/ hom.1982.368323

Quirós, J. (2015). Etnografiar mundos vívidos. Desafíos de trabajo de campo, escritura y enseñanza en antropología. Publicar-En Antropología y Ciencias Sociales, $0(17)$. Recovered from http:/ /ppct. caicyt.gov.ar/index.php/publicar/article/view/4914

Restrepo, E. (2018). Etnografía : alcances, técnicas y éticas (1. a ed.). Lima: Fondo Editorial de la Universidad Nacional Mayor de San Marcos. Recovered from http://bdjc.iia.unam.mx/items/ show $/ 77$

Sahlins, M. (1997). Islas de historia: la muerte del capitán Cook metáfora, antropología e historia (3a.ed). Barcelona: Gedisa.

Sahlins, M. (2001). Dos o tres cosas que sé acerca del concepto de cultura. Revista Colombiana de Antropología, (37), 11.

Sharma, D. (2016, febrero 11). Everybody's an Ethnographer! Recuperado 19 de noviembre de 2018, de https: / / ethnographymatters.net/blog/2016/02/11/everybodys-an-ethnographer/

Stocking, G. W. (1985). The Ethnographer's Magic. Fieldwork in British Anthropology from Tylor to Malinowski. En G. W. Stocking (Ed.), Observers observed: essays on ethnographic fieldwork (Nachdr., pp. 70-120). Madison, Wis.: Univ. of Wisconsin Pr.

Shah, A. (2017). Ethnography? Participant observation, a potentially revolutionary praxis. HAU: Journal of Ethnographic Theory, $7(1), 45-59$.

Van Velsen, J. (1978). The Extended-case Method and Situational Analysis. En A. L. Epstein (Ed.), The Craft of social anthropology (pp. 129-149). Oxford ; New York: Pergamon Press. 
Wacquant, L. J. D. (2006). Entre las cuerdas: cuadernos de un aprendiz de boxeador. Buenos Aires: Siglo XXI.

Wang, T. (2013, mayo 13). Big Data Needs Thick Data. Recovered November, 19th, 2018, from https://ethnographymatters. net/blog/2013/05/13/big-data-needs-thick-data / 